in Science

through time and space
Жамият ва инновациялар -

Общество и инновации Society and innovations

Journal home page:

https://inscience.uz/index.php/socinov/index

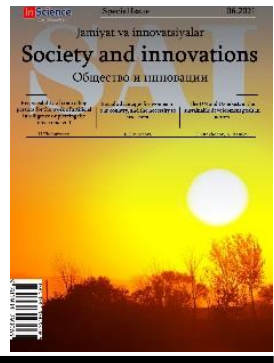

\title{
The development of exchange rate systems in Central Asia - history and current policy initiatives
}

\section{Mukhayo ABDULLAEVA ${ }^{1}$, Sayyora TORAEVA ${ }^{2}$}

Bukhara Regional Centre for Training and Retraining of Public Education Staff

Surkhandarya Regional Centre for Training and Retraining of Public Education Staff

\section{ARTICLE INFO \\ Article history: \\ Received May 2021 \\ Received in revised form \\ 20 May 2021 \\ Accepted 15 June 2021 \\ Available online \\ 15 July 2021}

\footnotetext{
Keywords:

exchange rate system,

central bank,

currency,

monetary policy,

Uzbek som,

tenge, somoni,

Kyrgyz som,

analytical capacity,

foreign exchange rates,

interest rates,

price stability.
}

\begin{abstract}
The article discusses the topic of history of exchange rate system development in Central Asian countries including Kazakhstan, Uzbekistan, Kyrgyzstan and Tajikistan along with central banks' current policy initiatives. Report includes the analysis of the IMF reports regarding the above mentioned countries and some extra literature referring to the topic.
\end{abstract}

2181-1415/C) 2021 in Science LLC.

This is an open access article under the Attribution 4.0 International (CC BY 4.0) license (https://creativecommons.org/licenses/by/4.0/deed.ru)

\section{O'rta osiyoda valyuta ayirboshlash sistemalari tarixi va hozirgi siyosiy tashabbuslar}

\author{
Kalit so'zlar: \\ Valyuta ayirboshlash \\ sistemasi, \\ markaziy bank, \\ pul birligi, \\ moliyaviy siyosat, \\ o'zbek so'mi, \\ tenge, somoniy, \\ qirg'iz so'mi, \\ analitik salohiyat, \\ valyuta kurslari, \\ foiz, \\ narx stabilligi.
}

ANNOTATSIYA

Ushbu maqola O'rta Osiyodagi davlatlarda, xususan, Qozoqiston, O'zbekiston, Qirg'iziston va Tojikistondagi valyuta va pul ayirboshlash sistemlarai rivojlanish tarixi va ushbu davlatlardagi markaziy banklarning hozirgi kundagi siyosiy tashabbuslarini muhokama qialdi. Shuningdek, maqola Xalqaro Pul Fondi axoborotlari tahlili va mavzuga oid bo'lgan bir nechta boshqa adabiyotlarni ham o'z ichiga oladi.

\footnotetext{
${ }^{1}$ Senior lecturer, Bukhara Regional Centre for Training and Retraining of Public Education Staff. Bukhara, Uzbekistan. E-mail: mukhayo.abdullaeva@mail.com.

${ }^{2}$ Senior lecturer, Surkhandarya Regional Centre for Training and Retraining of Public Education Staff. Surkhandarya, Uzbekistan.
} 


\section{Развитие систем валютного обмена в Центральной Азии - история и текущие политические инициативы}

\author{
Ключевые слова: \\ валютная система, \\ центральный банк, \\ валюта, \\ денежно-кредитная \\ политика, \\ узбекский сом, \\ тенге, \\ сомони, \\ кыргызский сом, \\ аналитический потенциал, \\ валютные курсы, \\ процентные ставки, \\ стабильность цен.
}

АННОТАЦИЯ

В статье обсуждается история развития валютной системы в странах Центральной Азии, включая Казахстан, Узбекистан, Кыргызстан и Таджикистан, а также текущие политические инициативы центральных банков. Статья включает анализ отчетов МВФ по вышеупомянутым странам и некоторую дополнительную литературу по данной теме.

\section{INTRODUCTION}

The current paper will discuss the development of exchange rate systems in Central Asia, mainly Kazakhstan, Kyrgyzstan, Tajikistan and Uzbekistan. Along with evolution of independent monetary policy and national currency in these post-Soviet Union countries, historical and current policy initiatives will be reviewed and analyzed. Moreover, the information provided is backed by the articles and reports by IMF, Central Banks and government entity publications. Lastly, the efficiency of current government policies in Central Asian countries is discussed and recommendations are given where possible.

\section{MAIN BODY}

Kazakhstan. Development of exchange rate in Kazakhstan since 1990s and early policies Kazakhstan initiated its independent monetary policy from November $15^{\text {th }}$ of 1993 after the collapse of the Soviet Union's rouble zone. Despite the fact that Soviet Union dismembered the rouble remained in all successor states since it was supported by numerous international economic entities. However, hyperinflation stroke in rouble zone after deregulations in January 1992 and there was observed a 250 percent inflation in prices for the single month of January. Moreover, by the end of 1992 the prices increased by 26 times compared to previous year indicators. The rouble reached its ending term in July 1993 when CBRF required daily bilateral clearings between the former Soviet Union countries and Russia making the rouble banknotes issued by 1993 no more legal (IMF, 1999). This led countries including Central Asia to introduce their own currency.

On September 7, 1993 a treaty was signed to coordinate monetary policy and stabilize exchange rates in countries between Russia, Kazakhstan, Uzbekistan, Tajikistan, Armenia and Belarus. The bilateral agreement loses its power in several weeks. Thus, Kazakh government introduced its national currency Tenge (KZT) on November 15 1993.

After the issuance of KZT, the National Bank of Kazakhstan increased reserve requirements for commercial banks from 20 to 30 percent. The refinancing rates rose from 170 percent to 240 percent from November till December of 1993 and reached 270 percent in the following month (IMF, 1995). The national currency was let to freely float in the international market with minor intervention to smooth and then switching to 
not to control trend. The exchange rate was initially was 5 KZT/USD in 1993 and then rose to $70 \mathrm{KZT}$ in three years. Credit loans from NBK to commercial banks decreased for $10 \%$ (from $25 \%$ to lower than $10 \%$ ); Thus, inflation gradually reduced and by the year 1994 KZT depreciation reflected patterns of stabilization (IMF, 2018).

\section{Privatization}

In order to achieve rapid growth and compensate deflation along with recessive monetary policy rapid privatization and liberalization policies were chosen. Thus, when privatization was implemented in the place where there was a lack of effective financial market, competitive entrepreneurs and strong financial institutions, resources failed to be effectively allocated. Instead of bringing efficiency and increasing supply in markets, privatization led the entire spheres to be swept away. This in turn, caused supply to decrease, inflation increased and brought the economy towards stagnation.

\section{Chart 17 - Share of Privatised Firms}

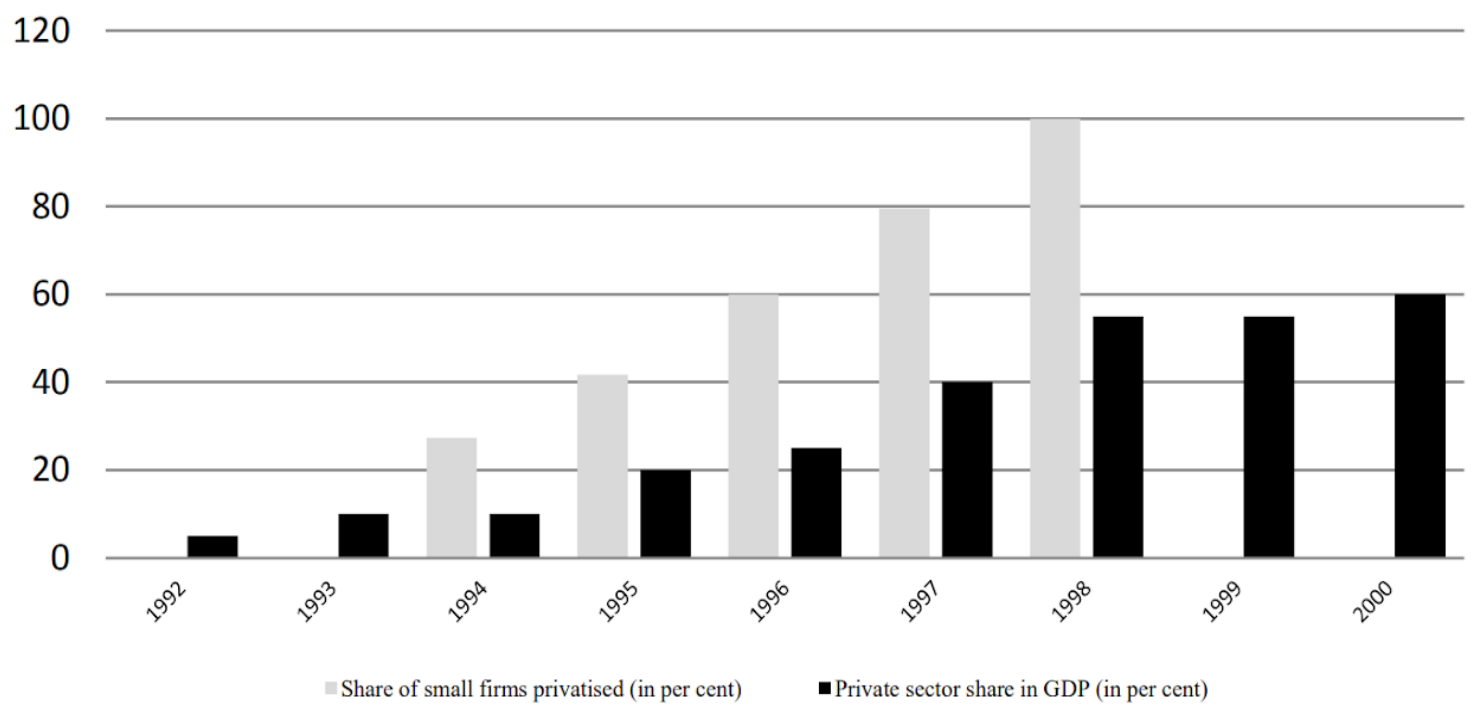

Source: Celetti, D. (2019). Trends in a transition economy: Kazakhstan's monetary policy after independence

Price liberalization was also anticipated to be effective. However, it proved problematic. Ideally, increasing the consumer price by three to five times should have led to stabilization and to new equilibrium level of supply and demand. Moreover, there was expected an in increase in production caused by new price levels and demand sustained by competitiveness of privatized business entities.

Actually, price liberalization caused a negative trade balance due to increased imports which was favored by rapid resource allocation. This shifted the investment towards export-oriented economic branches in the form of raw materials, trade services and energy causing a long-term downturn in the consumer-oriented firms domestically. These all had negative effect on the state budget, currency value and global position of Kazakhstan (IMF, 2016). 
Current Account Balance

(Percent of GDP)

\begin{tabular}{lrrr}
\hline & 2013 & 2014 & 2015 \\
\cline { 4 - 4 } & & & est. \\
\hline Oil exporters & & & \\
Azerbaijan & 16.4 & 13.9 & 0.2 \\
Kazakhstan & 0.4 & 2.8 & -2.6 \\
$\quad$ Turkmenistan & -7.2 & -6.7 & -12.7 \\
Uzbekistan & 2.9 & 0.7 & 0.0 \\
Oil importers & & & \\
Armenia & -7.6 & -7.3 & -3.2 \\
Georgia & -5.8 & -10.6 & -11.6 \\
Kyrgyz Republic & -15.0 & -16.7 & -14.7 \\
Tajikistan & -2.9 & -9.7 & -10.2 \\
\hline
\end{tabular}

Source: IMF (2016). Exchange rate Developments and Policies in the Caucasus and Central Asia

\section{The recent historical overview in the exchange rate system}

By the end of 2014, exchange rate regimes and the exchange rates in the Caucasus and Central Asia have come under pressure. This was followed by the decline in the oil prices along with commodity prices, decrease in the growth of countries like Russia and China, ruble depreciation and USD appreciation which are all the dependent variables of CCA currency exchange rates. Primitive fiscal policies and current account balances on top of increased dollarization have even more complicated the overall image. At that time all CCA countries had closely managed exchange rate regimes, usually have their currencies overvalued (IMF, 2016). The main objective of all Central banks of CCA countries have been presented as price stability and most CBs have relied on the exchange rate stability to achieve the price stability. Thus, the initial policy was intervention to local foreign exchange markets though with limited communication. The adoption of floating exchange regime by Kazakhstan in 2015 has been a key driver according to IMF's valuation.

Currently, the National Bank of Kazakhstan is proposing ways to further straightening its monetary policy. The NBK has successfully accomplished enhancing its inflation leveling structure, policy research, analytical capacity along with communication between the markets and the public sectors. Moreover, the NBK noted that efforts should be made on the maintaining and further enhancement of the efficiency and transparency of monetary policy following the below listed tools and guidance:

\section{- Liquidity management.}

NBK notes have been playing key role in fighting against surplus liquidity having limited access to government securities. Thus, in order to reduce the volatility of the interest rate in the swap market, the NBK presented new technique for liquidity provision and withdrawal which was a one-day FX swap. It was suggested by the staff that it should be as a collateral in open-market procedures. Moreover, in terms of banking system liquidity, reviewing reserve requirements should be guaranteed. According to Staff, RRs for residents and non-residents has to be unified in order to avoid discrimination of 
residency. Moreover, IMF's institutional view suggests to increase RR rates and introduce remuneration of RRs. Furthermore, it is advised to keep differentiated RR rates for FX and tenge deposits.

- Securities market development.

The current securities market is considered to be underdeveloped. Introduction of project between the NBK and Clearstream is welcomed since it will let government and NBK securities denominated by tenge through its platform providing access for foreign investors.

- Exchange rate (ER) policy.

The Staff of the NBK noted that floating exchange rate is helping Kazakhstan to engage changes in the macro level along with supporting de dollarization. Exchange rates have been essential factors as well as oil prices and Russian ruble for Kazakhstan. Strong transparency and communications between FX purchases and sales would have benefit the National Bank of Kazakhstan taking into account NFRK and UAPF (IMF, 2018).

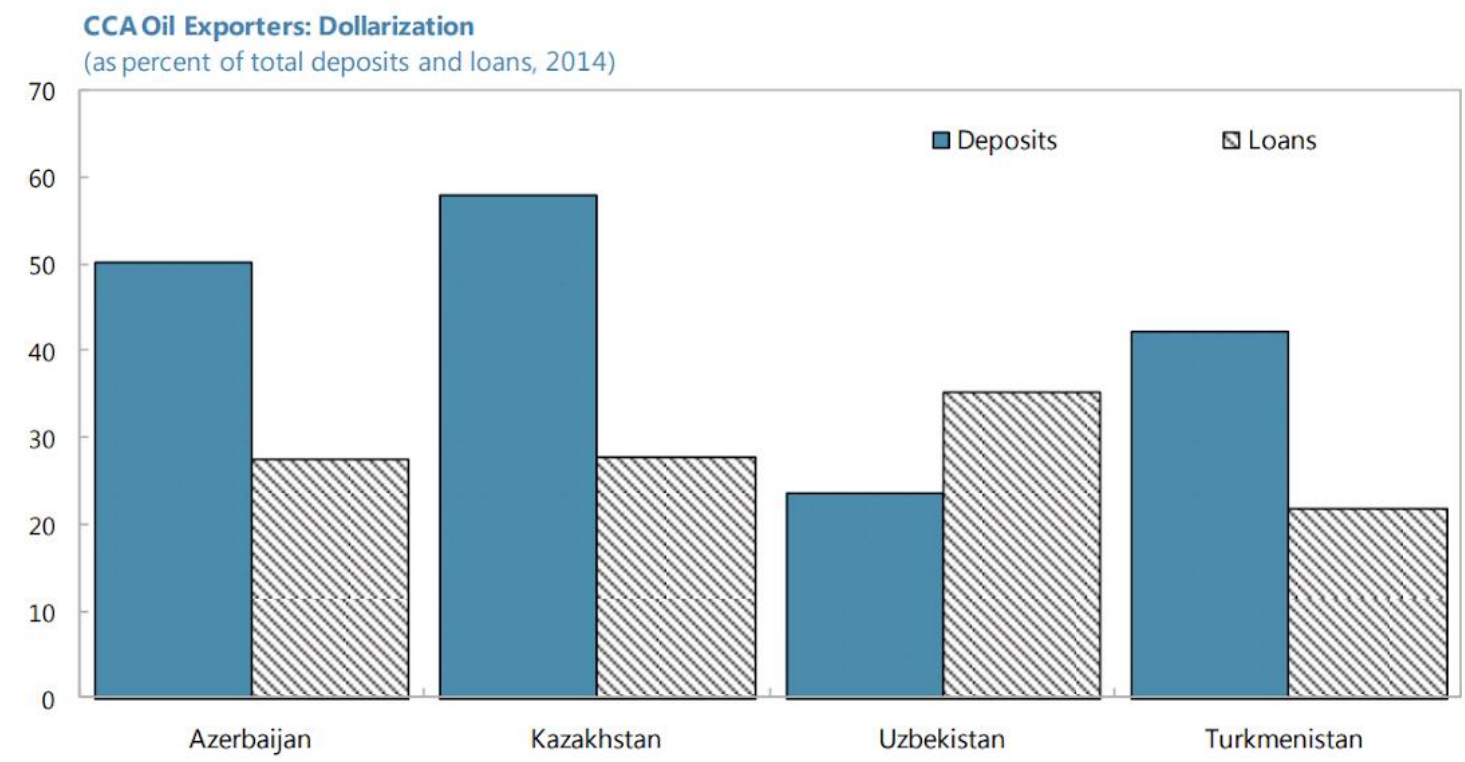

Source: IMF (2016). Exchange rate Developments and Policies in the Caucasus and Central Asia

Government's current initiatives to make sustainable exchange rate policies

The governments of Kazakhstan implemented an economic support program as a reaction to the devaluation that took place in 2014 which constituted 1 trillion tenge which was equivalent to 5.5 billion USD in 2014-2015 years (Komekbayevaet. Al, 2016). These funds were intended to solve bank loan issues to buy out non-performing loans along with supporting small and medium size businesses.

Another program that was launched by the governments was titled 'Nurly Jhol' (The path to the future) with the amount of 14 million USD. This program was launched due to drop in oil prices and slow slowing down economy with a view to providing support to small businesses and building social infrastructure and transportation.

The main current monetary policy approved by NBK is inflation targeting which was set in 2015 and operated under the label of 'Monetary Policy of the Republic of Kazakhstan to 2020 '. It has been highlighted that reducing and stabilizing inflation at low levels could 
increase confidence of the national bank markets and bring sustainable economic growth to Kazakhstan. For this very reason inflation targeting was chosen as a desirable monetary policy.

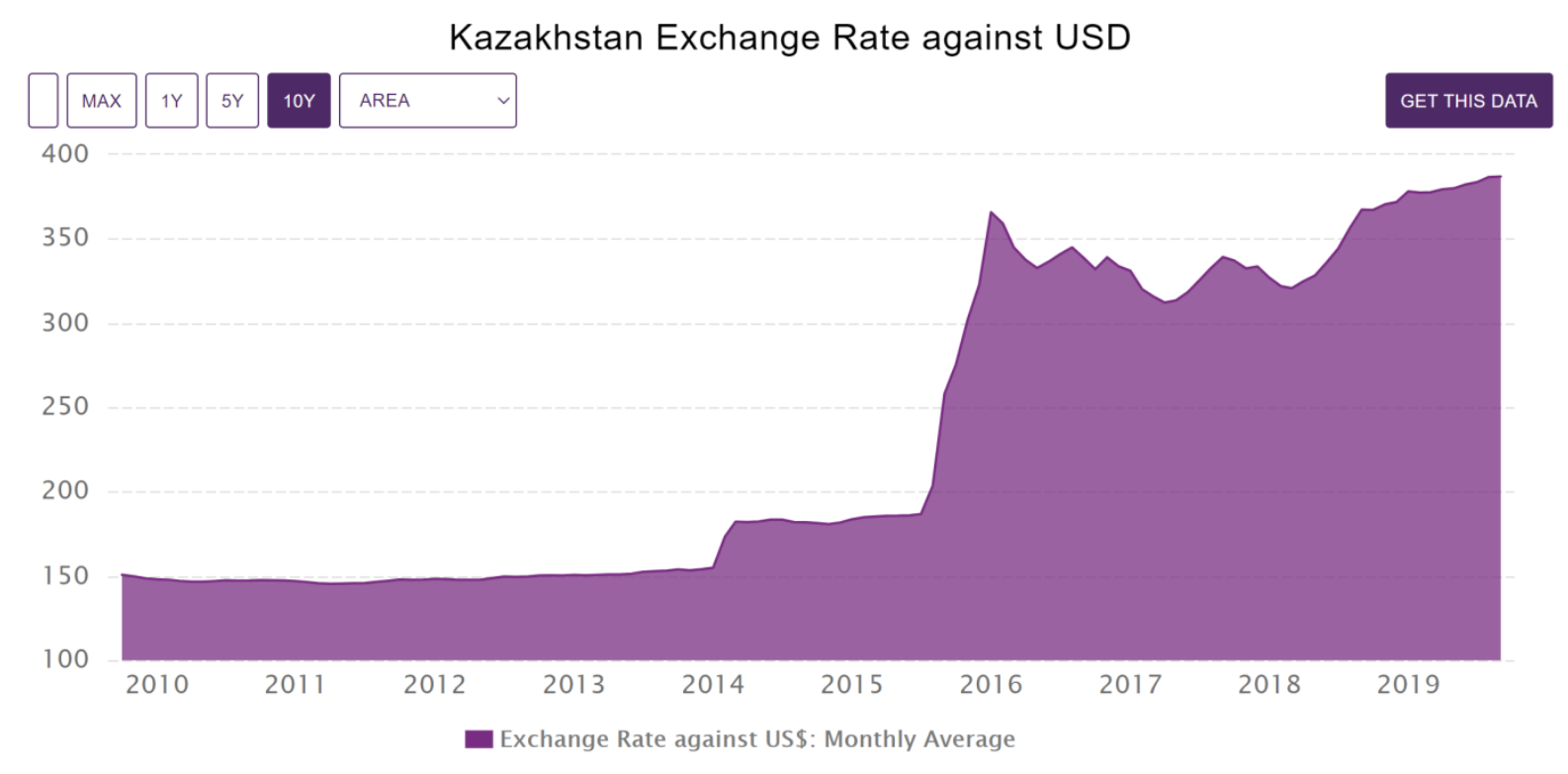

Source: CIEC, 2020 https://www.ceicdata.com/en/indicator/kazakhstan/exchange-rateagainst-usd

\begin{tabular}{|l|c|c|}
\hline \multicolumn{3}{|c|}{ Table 1. CCA ER Arrangement AREAER ${ }^{2}$ Classification } \\
& (as of March 2016) \\
\hline & De Jure & De Facto \\
\hline Armenia & Free floating & Floating \\
\hline Azerbaijan & Managed floating & Stabilized \\
\hline Georgia & Floating & Floating \\
\hline Kazakhstan & Managed floating & Other managed arrangement \\
\hline Kyrgyz Republic & Floating & Other managed arrangement \\
\hline Tajikistan & Managed floating, & Other managed arrangement \\
\hline Turkmenistan & Co predetermined path & \\
\hline Uzbekistan & Managed floating & Crawl-like arrangement \\
\hline
\end{tabular}

Source: IMF (2016). Exchange rate Developments and Policies in the Caucasus and Central Asia

\section{Kyrgyzstan}

\section{INTRODUCTION}

The fall of the Soviet Union in the early 1990s marked the inception of the liberalization of Central Asian economies, and once-interdependent countries were to rebuild their economies through the adoption of economic policies as well as reforms in 
their financial systems. However, it was not until after 1993 when these countries initiated sweeping currency reforms and adopted their national currencies (Karshibaev, 2015). Those reforms were followed by reluctant efforts to transition to a more flexible Exchange Rates regime, and this gave rise to the emergence of black markets where currencies would be traded at much higher values than dictated by the central banks. An IMF report (2016) on Exchange Rate developments and policies in Central Asia reads that such reluctance to facilitating a greater ER-flexible environment in these countries, which have been the case until quite recently, can be attributed to a host of factors, such as but not limited to, concerns with ER volatility, lack of monetary tools to absorb external shocks, underdeveloped financial markets, political uncertainties affecting the economy, and high liability dollarization. Faced with these factors, the countries were either to utilize moneybased stabilization programs or allow free-floating exchange rates to gain access to the world market and make transactions with offshore traders. To further elaborate on the exchange rate systems in Central Asia, the exchange rate system in Kyrgyzstan will be described in more detail in this part of the report.

\section{A brief account of domestic currency and the ER system}

The Kyrgyz national currency, Kyrgyzstani Som, was issued on May 10, 1993, since when the country allowed floating exchange rates (Sarbanov, 1998a, p1). Prior to that and a few years after, the Russian ruble was still in use in many parts of the country. Later in this timeline in 1995, the currency market was fully liberalized with Kyrgyzstan signing Article 8 of the IMF Agreement on full convertibility of current and capital accounts (IMR, 2004). As figure 1 shows, the signing of the agreement meant a small depreciation of $10 \%$ on account of Kyrgyz som which amounted to 11 to 1 USD towards the end of 1995 . The graph also illustrates that Kyrgyz som gradually depreciated by $75 \%$ against the US dollar over the last 20 years. Devaluation of this degree was triggered by numerous factors: fall in exports and increase in imports towards the end of the 1990s caused by Kyrgyz goods losing competitiveness against Kazakhstan exports, the Russian crisis which meant the further depreciation of Russian ruble and Kyrgyz som in turn, and a range of monetary policies subordinated to fiscal policies which were indicative of central bank dependence. As of December 20 (updated), the exchange rate is 83.6 Kyrgyzstani som per 1 USD (XE Currency Convertor, 2020).

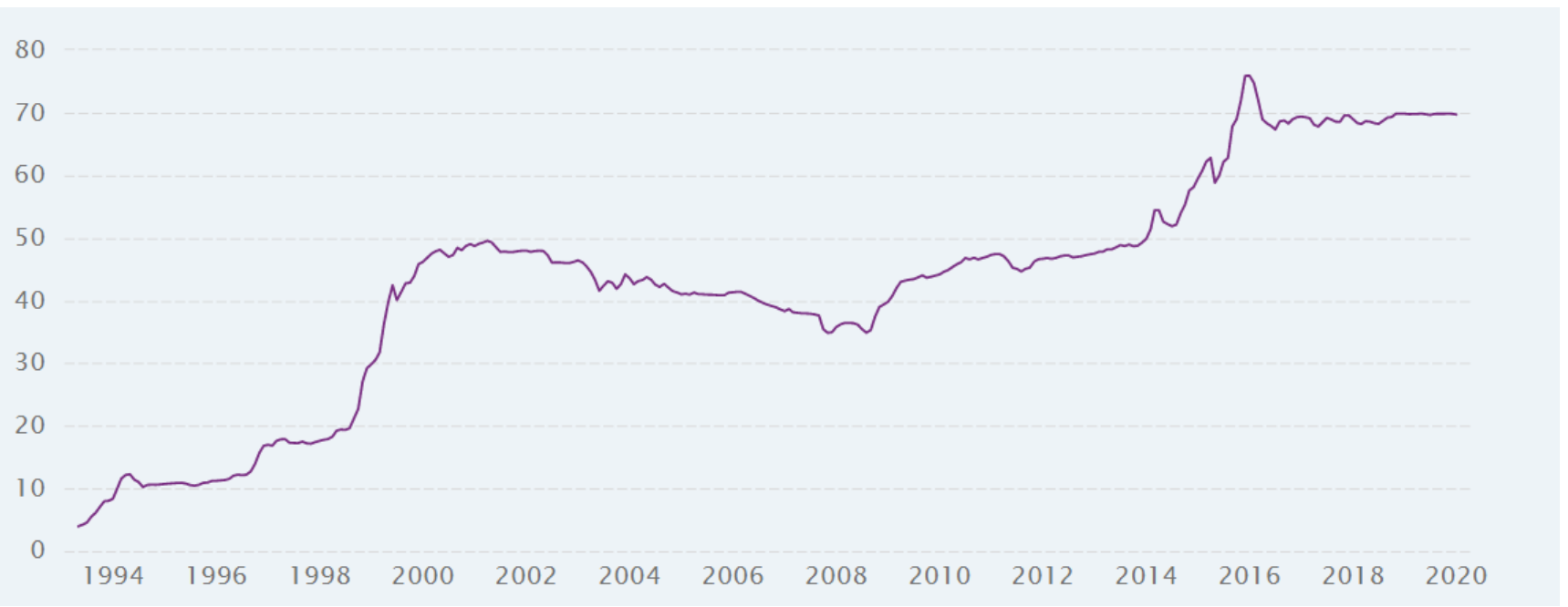

Figure 1. Kyrgyzstan's exchange rate against USD from May 1993 to October 2020. (Source: ciecdata.com) 


\section{Policy changes and reforms}

The healthy functioning of the Exchange Rates system goes hand in hand with the extent of independence the central bank exercises within its authority. The National Bank of Kyrgyz Republic had been utilizing monetary instruments to regulate inflation rates and smoothing out inflationary fluctuation until quite recently though these practices are being abandoned to allow more central bank independence (Sarbanov, 1998b, P. 5). Two of such practices were currency auctions and secrecy of information regarding public inflationary expectations. The former one essentially involved currency interventions to artificially adjust the value of the domestic currency against the US dollar, and this practice was discontinued by the end of 1998. The letter one, which was not to reflect the fluctuations in the exchange rate of the US dollar in inflation rates, was broadly applied to encourage the public to keep savings in the form of national currency.

One of the fundamental actions taken to liberalize the financial market in Kyrgyzstan was to pass the floating exchange rate policy in May 1993. This allowed the free market exchange rates to be reflected in the value of the domestic currency (Igamberdiev, 2015a). The exchange rate kept its stability until 1996 when expansionary monetary policy was pursued to print money and pay domestic debts. More than that, an increase in the deficit of account balance further devaluate the domestic currency, leading to a hefty $33 \%$ depreciation in the value of Kyrgyzstani som against USD in 1996 alone. The resulting shortage in foreign currency reserves was offset by international loans from overseas financial institutions and IMF (Igamberdiev, 2015b). Following the Russian crisis and a huge depreciation in national currency, the country implemented long-term currency appreciation policy to up the value of its currency. As a result, Kyrgyzstani som appreciated from 2001 to all the way to 2007 as shown in figure 1. This appreciation in national currency meant higher volumes of imports and lower volumes of exports, causing trade imbalance of historical levels. Another tool used to facilitate a flexible ER environment has been Dollarization. Shortly after 2007, there was a growing trend towards dollarization of accounts, and this was extensively pursued until 2009 as shown in figure 2 . From 2009 to 2012 , foreign currency deposits fell by about $20 \%$. This fall in the percentage of foreign currency deposits was followed by an increase of $15 \%$ in foreign currency deposits until June 2015 (IMF, 2016).

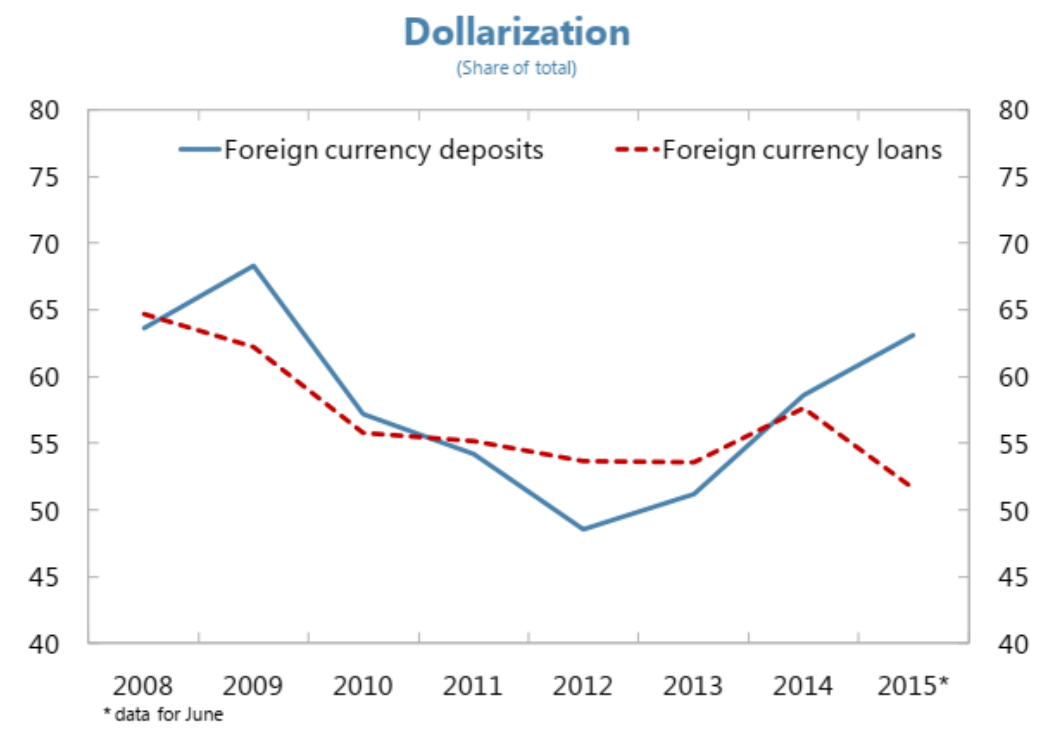

Figure 2. Dollarization: Foreign currency deposits and loans. (Source: IMF, 2016) 


\section{Tajikistan}

The development of exchange rate in Tajikistan and early policies.

Until the collapse of the Soviet Union, the 'ruble' was in circulation in Tajikistan until January, 1994 as well as in all other Central Asian countries. After the independence in 1991, the country couldn't manage to keep its currency in circulation because of the civil conflicts which lasted from 1992 to 1997. On May 10th, 1995, national currency under the name of 'TadjikRuble' was accepted as the official currency of the Republic of Tajikistan. At the time, the country imposed its very first monetary policy and therefore, the economy was positively influenced. However, during the period of being the national currency, tajikruble highly depreciated against other foreign currencies. Thus, in October 29, 2000, the government of the Republic of Tajikistan made a decision to introduce a new currency which was 'samoni' - TJS. At the time, it was equivalent of 1000 RUB and 1/3 USD. From that time, the main aim of the political policy was to reduce inflation. The year of the issuance of a new currency was followed by significant depreciation in average real exchange rate. Following the advices from IMF, local government decided to limit the foreign currency interference in order to moderate the temporary exchange rate fluctuations. That is, authorities kept the flexible exchange rate policy as the economy was extremely vulnerable to exogenous shocks. The following year, government extracted its deposits with the NBT and thus, net lending rose considerably, however, NBT did not lend any new loans to the government.

\section{Monetary policy and exchange rate regimes.}

The prime aim of the NBJ's as well as of the government monetary policy is to stabilize exchange rate and price. As a result of recent exogenous shocks including dramatic remittance decrease, which is considered to be one the main drivers of the economy, caused by the Russia's economic downturn as well as the decline in prices of cotton and aluminium, the local currency, TJS, experienced strong downfall in value. NBT's response to the external shocks was to sell USD in great amounts in the forex market. Consequently, initially low reserves of international funds even declined. In spite of the efforts taken by the Central Bank of Tajikistan, local currency, TJS depreciated dramatically by $60 \%$ in the period from 2014 to 2016 :

\begin{tabular}{|c|c|c|c|}
\hline Year & Afghanistan & Kyrgyzstan & Tajikistan \\
\hline 2010 & 46.5 & 46.0 & 4.4 \\
\hline 2011 & 46.7 & 46.1 & 4.6 \\
\hline 2012 & 50.9 & 47.0 & 4.7 \\
\hline 2013 & 55.4 & 48.4 & 4.8 \\
\hline 2014 & 57.2 & 53.7 & 4.9 \\
\hline 2015 & 61.1 & 64.5 & 6.2 \\
\hline 2016 & 67.9 & 69.9 & 7.8 \\
\hline
\end{tabular}

Source: World Development Indicators, World Bank 
NurbekJenish (2019) believes that the presence of insolvent banks in the country would seriously decreases the liquidity which, in turn, may cause more challenges on the TJS and thus, increase inflation. Moreover, local currency as well as the foreign ones still appears to hold increased spread of interest rates which is caused by inefficient transaction services including banks and other financial enterprises. One can say that, all of the above mentioned challenges and economic inefficiencies including reduced reserves of foreign currencies, financial sector problems and the persisting devaluation the national currency make the goals of economic stability and prosperity hardly achievable.

\section{The recent historical overview of exchange rate systems.}

In the last six years, a fall in the prices of oil as well as other commodities, RUB devaluation and anticipated rise in Federal rates caused a great pressure on the currencies of Central Asians Countries. Strong dependence of the CA currencies on USD has, in turn, caused dollar appreciation. All Central Banks of CA countries, including Tajikistan, share the common goal of price stability as the primary aim of their policy. Nevertheless, implementation of the policy requires different political instruments including exchange rate regimes and the interest rate:

\begin{tabular}{|l|c|c|}
\hline \multicolumn{3}{|c|}{ Table 1. CCA ER Arrangement AREAER ${ }^{2}$ Classification } \\
& (as of March 2016) \\
\hline & De Jure & De Facto \\
\hline Armenia & Free floating & Floating \\
\hline Azerbaijan & Managed floating & Stabilized \\
\hline Georgia & Floating & Floating \\
\hline Kazakhstan & Managed floating & Other managed arrangement \\
\hline Kyrgyz Republic & Floating & Other managed arrangement \\
\hline Tajikistan & Managed floating, & Other managed arrangement \\
\hline Turkmenistan & Conventional peg & Conventional peg \\
\hline Uzbekistan & Managed floating & Crawl-like arrangement \\
\hline
\end{tabular}

Dramatic decrease in remittances along with pour export gaining in 2016, considerably affected exchange rates in a negative way:
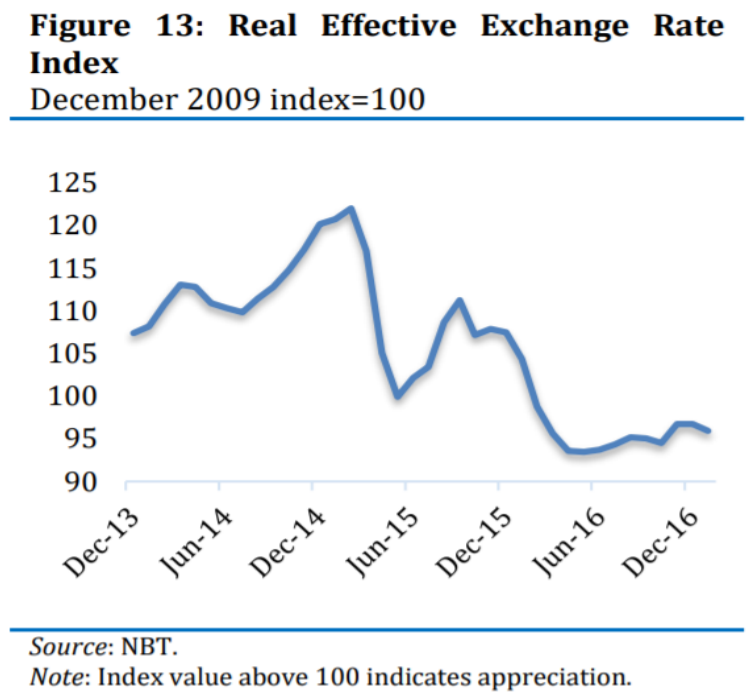
The response of the government to the problem was to impose some administrative estimates such as, putting end to foreign exchange cabins, 1:2 surrender demand and compulsory exchange of foreign remittances to local currency - TJS. As a result, the local currency, somoni, stabilized to some extent and entered to some other segments in the market. The government further supported the policy by increasing penalties for the individuals who illegally utilize foreign exchange. In the end of the year, authorities ended up with around 11\% depreciation of the local currency against USD. However, because of the changes in liquidity policy, the next year started with the pressure bounds on exchange rates within the country. Next, different monetary policy was implemented by the National Bank of Tajikistan which contained expansion of maturity periods up to half a year and introduction of new option which offered 24-hour repurchase programs in order to improve the liquidity requirements. At the time, authorities maintained a float exchange rate regime.

The International Monetary Fund Executive Board (2019) concludes that aggravation of external account of the Republic of Tajikistan took place due to the decrease in remittances as well as exports, and an increase in exports. Appreciation of real exchange rate happened and country encountered the problem with foreign exchange deficiency.

\section{Ongoing Structural Reforms}

The recent COVID-19 shock have negatively impacted the country which resulted in price fluctuations and exchange rate volatilities. However, the implementation of the monetary policy instruments happened to soften the downturn. Currently, authorities are going the continue with the development of efficient monetary and exchange rate policies to achieve the ultimate goal of long-term price stability. The NBT (2020) informs that country will go on with the National Development Strategy of the Republic of Tajikistan for up to the next ten years. The main target of upcoming exchange rate policies is to reformation of financial institutions, vitalizing policy tools together with improving transmission on the short term interest rates, stabilizing the inflation.

\section{Uzbekistan}

In 2017, President of Uzbekistan Shavkat Mirziyoyev signed a decree "On Priority Measures to Liberalize Monetary Policy", providing for the introduction of free conversion for legal entities and individuals, stated in the website of the head of state. According to the document, starting from September 5, legal entities of Uzbekistan can without restrictions purchase foreign currency from commercial banks to pay for current international transactions (import of goods, works and services, repatriation of profits, repayment of loans, payment of travel expenses and other transfers of a non-commercial nature). Individual entrepreneurs without forming a legal entity engaged in the import of consumer goods can purchase foreign currencies through bank accounts in accordance with the procedure established for individuals. The requirement for the obligatory sale of foreign exchange earnings in foreign currency of exporters, regardless of the form of ownership, is completely abolished. Individual entrepreneurs without a legal entity, as well as farms with income in foreign currency, can withdraw cash in foreign currency from their bank accounts.

Currency conversion in Uzbekistan seems to have ended. Since 2019, in exchange offices of banks in the country, you can exchange not only dollars, euros, British pounds, Japanese yens and Swiss francs for Uzbek sums, but also, conversely, buy cash dollars, euros and three other types of currencies for sums. As part of the implementation of 
measures for further liberalization of the exchange market from August 20 of this year. Commercial banks have started selling foreign currency in cash through exchange offices. To exchange soums for dollars and other currencies, you must come with a passport. They do not put a mark in the passport, but they copy it, enter various information from it into the computer - this takes quite a long time. Fortunately, there was no queue to the window, so you can be patient.

By January 1997, about 16 percent of Uzbekistan's GDP had been transferred from exporters to importers at 2-8\% of GDP in import markets and up to 15\% in export markets losses were observed. The reason for this is the growing gap between exchange rates. The analysis of social security shows the following optimal conclusions about the reform strategy: (i) if the exchange rates are combined, the social losses will decrease, (ii) this merger will be complemented by changes in the specific tax system, (iii) at least, Uzbekistan will benefit from the transition to a clear fiscal regime.

Uzbekistan and Turkmenistan are the only countries among the countries of the Baltics, Russia, and other countries of the former Soviet Union that have strong export and import management segmented in the foreign exchange market. After the period of currency and trade liberalization in 1995-96, an emergency system was created as a response to the increase in balance of payments pressure after the unexpected deterioration of the country's trade conditions.

This is the second official segment of the Uzbek currency market commercial banking market, where commercial banks and exchange offices trade. Here the currency is exchanged with other banks, enterprises and individuals and the official exchange rate is freely set. That was until mid-1998 if the rate does not exceed $12 \%$ of the auction market. After the decree of July 1, 1998, this figure increased upwards. In 1997 and 1998, it was required to hand over 30 percent of all foreign exchange earnings from decentralized (i.e., gold and non-cotton fiber) exports. On January 1, 1999, the surrender requirement was increased by 50 percent. The compulsory surrender was to be at the auction rate by July 1,1998 , but now at the rate of a commercial bank. Buy / sell in this regard the distribution of funds for commercial banks was reduced from 12 per cent to about 3 per cent. In addition, for centralized exports, the Central Bank of Uzbekistan (CB) sells foreign currency at full value to commercial banks. Thus benefiting from the Central Bank's growing spread between the auction rate and traders in the commercial banking market have also been allowed to sell foreign currency, but will have to obtain a special license and currency quota from the Republican Monetary Commission (RMC). Individuals, on the other hand, can only use this opportunity for very limited purposes, such as pilgrimage or authorized study abroad.

\section{DISCUSSION}

These strict rules have led to the emergence of an informal (illegal) market in the foreign exchange market, where unsatisfactory demand has been met in the other two official markets. However, as mentioned above, by 2017 , this black market was completely eliminated. 


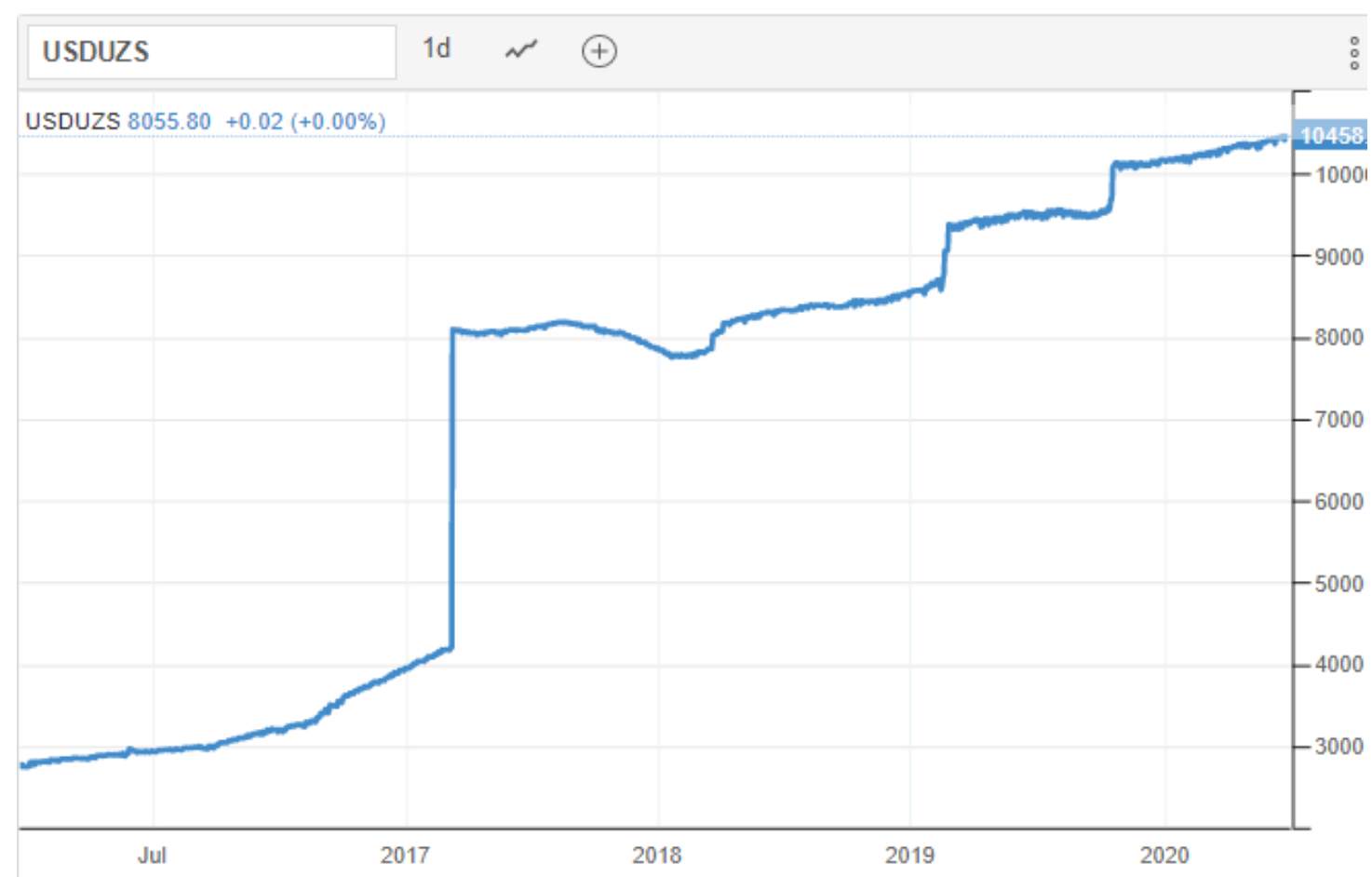
2020)

(Uzbekistani Som | 2013-2020 Data | 2021-2022 Forecast | Quote | Chart | Historical,

In addition, the third segment is the non-cash offshore curb market, in which the exchange rate was depreciated by up to $50 \%$ compared to others, which was later excluded from the rest of this market segment. The reason for this is the restrictions imposed by the Central Bank of Uzbekistan.

\section{RESULTS}

According to the interview for the French financial newspaper La Tribune by Galina Saidova, Deputy Adviser to the President on Development of Economic Sectors, Implementation of Investment and Foreign Trade Policy, former Minister of Economy of the country (2011-2017), the previous economic model led to the creation of a system of double or even triple exchange rate of the Uzbek soum against the US dollar, thereby stimulating the black market and the informal economy (Ouzbékistan : réformes au "far East", rebond en vue après la Covid-19, 2020). Moreover, in the transition report of 2017-18 it is stated that according to the decree of the President of the Republic of Uzbekistan ShavkatMirziyoyev dated February 2, from September 5, the Central Bank set the exchange rate of the administrative currency and devalued the official exchange rate by 48\% (Transition Report 2017-18: Sustaining Growth, 2020).

\section{CONCLUSION}

The authorities have pledged to maintain both exchange rate flexibility and use reserve buffers in a disorderly market environment. The Central Bank of Uzbekistan (CBU), while maintaining its intervention, has developed a policy restricting foreign exchange in the purchase of locally produced gold and easing fluctuations in the foreign exchange market. This policy has contributed to the stabilization of our exchange rate against the dollar after the devaluation in August 2019. Coming to April 2020, the exchange 
rate of UZS / USD depreciated six percent. The continued presence of exchange rate pressures guarantees more flexibility of exchange rates and the target currency. Its performance can be improved by establishing certain systemic barriers in the foreign exchange market. For example, setting up a platform for over-the-counter foreign exchange transactions through the implementation of a consolidated program and setting the CBU reference rate daily rather than weekly. (Republic of Uzbekistan: Requests for Disbursement under the Rapid Credit Facility and Purchase under the Rapid Financing Instrum, 2020).

\section{REFERENCES:}

1. Ansor (2020). Tajik Currency: Somoni. Currency Rates in Tajikistan. Available from: http://life.ansor.info/en/tajik-currency-money-somoni/ [Accessed on December 19].

2. Celetti, D. (2019). Trends in a transition economy: Kazakhstan's monetary policy after independence. Available from https://doc-research.org/wp-content/uploads/2019/06/ Monetary-Kazakhstan_Download-file.pdf [Accessed November 28, 2020].

3. CIEC (2020). The exchange rate KZT against USD. Available from https://www. ceicdata.com/en/indicator/kazakhstan/exchange-rate-against-usd [Accessed December $10,2020]$.

4. Igamberdiev B. (2015). Exchange Rate Policy and Economic Reality in Kyrgyzstan. International Ataturk Ala-Too University. Available from: <https://www. academia.edu/23487420/Exchange_rate_policy_and_economic_reality_in_Kyrgyzstan $>$. [Accessed 2 December 2020].

5. IMF (2014). Monetary Policy in Hybrid Regimes: The Case of Kazakhstan. Available from https://www.imf.org/external/pubs/ft/wp/2014/wp14108.pdf [Accessed November 26, 2020].

6. IMF (2016). Exchange rate Developments and Policies in the Caucasus and Central Asia. Available from https://intranet.wiut.uz/Uploads/LearningMaterialFiles /10429/806/TW10_Seminar_Study\%20Material_Report\%20from\%20IMF_mcd1602.pdf [Accessed November 27, 2020].

7. IMF (2018). Republic of Kazakhstan. Available from https://www.imf.org/ / media /Files /Publications/CR/2018/cr18277.ashx [Accessed November 26, 2020].

8. International Monetary Fund. (2004). The International Monetary Fund and Current Account Convertibility. Washington D.C. Available from: <https://www.imf.org /external/np/leg/sem/2004/cdmfl/eng/elizal.pdf >. [Accessed 1 December 2020].

9. International Monetary Fund. (2016). Exchange Rate Developments and Policies in the Caucasus and Central Asia. Washington D.C. Available from: <https://www.imf.org /external/pubs/ft/dp/2016/mcd1602.pdf $>$. [Accessed 29 November 2020].

10. International Monetary Fund. (2016). Kyrgyz Republic: Selected Issues. IMF Country Report No. 16/56. Washington D.C. Available from: <https://www.imf.org/ external/pubs/ft/scr/2016/cr1656.pdf >. [Accessed 3 December 2020].

11. Karshibaev, J. (2015). Monetary Cooperation perspective in Central Asia. Procedia Economics and Finance 30 (2015) 388 - 400. Available from: <https://www.sciencedirect.com/science/article/pii/S2212567115013064/pdf?md5=c b3cff77f09fe9ecaa459d3effcc0d5d\&pid=1-s2.0-S2212567115013064main.pdf\&_valck=1>. [Accessed 29 November 2020].

12. Komekbayevaet. Al (2016). Government Measures for Economic Support in the Conditions of a Floating Exchange Rate of the National Currency. Available from 
https://www.iejme.com/download/government-measures-for-economic-support-inthe-conditions-of-a-floating-exchange-rate-of-the.pdf[Accessed November 26, 2020].

13. La Tribune. 2020. Ouzbékistan :Réformes Au "Far East", Rebond En Vue Après La Covid-19. [online] Available at: https://www.latribune.fr/opinions/ouzbekistanreformes-au-far-east-rebond-en-vue-apres-la-covid-19-863565.html [Accessed 14 December 2020].

14. Nurbek Jenish (2019), Macroeconomic Policy Frameworks and Technological Development: Case Studies of Kyrgyzstan, Tajikistan and Afghanistan. University of Central Asia. Available from: https://www.ucentralasia.org/Content/downloads/UCA-IPPAWp49\%20-\%20ENG.pdf [Accessed on December 18]

15. Sarbanov, U. (1998a). Challenges to Economies in Transition: Stabilization, Growth, and Governance International Conference in honor of the Kyrgyz som Bishkek, Kyrgyz Republic, May 27-28, 1998. Available from: <https://www.imf.org/external/np /eu2/kyrgyz/pdf/sarbanov.pdf >. [Accessed 30 November 2020].

16. Sarbanov, U. (1998b). Challenges to Economies in Transition: Stabilization, Growth, and Governance International Conference in honor of the Kyrgyz som Bishkek, Kyrgyz Republic, May 27-28, 1998. Available from: <https://www.imf.org/external/np /eu2/kyrgyz/pdf/sarbanov.pdf $>$. [Accessed 2 December 2020].

17. The International Monetary Fund (1996), Tajikistan: Recent Economic Developments. Available from: https://www.elibrary.imf.org/view/IMF002/066729781451836936/06672-9781451836936/06672-

9781451836936_A001.xml?redirect=true [Accessed on December 16]

18. The International Monetary Fund (2001). Tajikistan: 2001 Article Consultation with the Republic of Tajikistan. Available from: https://www.imf.org/external/pubs /ft/scr/2001/cr0165.pdf [Accessed on December 18, 2020]

19. The International Monetary Fund (2016), Exchange Rate Developments and Policies in the Caucasus and Central Asia. Monetary and the ER regimes in CCA. Available from:

https://intranet.wiut.uz/Uploads/LearningMaterialFiles/10429/1976/Horton_Samiei_E pstein\%20and\%20Ross_IMF_mcd1602.pdf [Accessed on December 17, 2020]

20. The International Monetary Fund (2020). IMF Executive Board Consultation with the Republic of Tajikistan. Available from: https://www.imf.org/en/News/ Articles/2020 /01/17/pr2012-tajikistan-imf-executive-board-concludes-2019-article-ivconsultation-with-the-republic [Accessed on December 19]

21. The National Bank of Tajikistan (2020). The Monetary and Exchange Rate Policies Strategy of Tajikistan. Available from: https://nbt.tj/en/monetary_policy /strategiya.php [Accessed on December 20]

22. Tradingeconomics.com. 2020. Uzbekistani Som | 2013-2020 Data | 2021-2022 Forecast | Quote | Chart | Historical. [online] Available at: https://tradingeconomics.com/ uzbekistan/currency [Accessed 5 December 2020].

23. Webcache.googleusercontent.com. 2020. Republic Of Uzbekistan: Requests For Disbursement Under The Rapid Credit Facility And Purchase Under The Rapid Financing Instrum. [online] Available at: https://webcache.googleusercontent.com/s earch? q=cache: GwSl0m81EfQJ:https://www.imf.org/ /media/Files/Publications/CR/2020/English/1UZBE A2020002.ashx $+\& c d=1 \& \mathrm{hl}=\mathrm{en} \& \mathrm{ct}=\mathrm{clnk} \& \mathrm{gl}=\mathrm{uz}$ [Accessed 21 December 2020].

24. Webcache.googleusercontent.com. 2020. Transition Report 2017-18: Sustaining Growth. [online] Available at: https://webcache.googleusercontent.com/search?q=cache: 
95xqxufhsS8J:https://www.ebrd.com/documents/oce/pdf-transition-report-201718uzbekistan.pdf $+\& \mathrm{~cd}=1 \& \mathrm{hl}=\mathrm{en} \& \mathrm{ct}=\mathrm{clnk} \& \mathrm{gl}=\mathrm{uz}$ [Accessed 20 December 2020].

25. Webcache.googleusercontent.com. 2020. Transition Report 2017-18: Sustaining Growth. [online] Available at: https://webcache.googleusercontent.com/search?q=cache: 95xqxufhsS8J:https://www.ebrd.com/documents/oce/pdf-transition-report-201718uzbekistan.pdf $+\& \mathrm{~cd}=2 \& \mathrm{hl}=\mathrm{en} \& \mathrm{ct}=\mathrm{clnk} \& \mathrm{gl}=\mathrm{uz}$ [Accessed 8 December 2020].

26. World Bank (2017), Tajikistan: Strong growth with a challenging outlook. Assessment of monetary and exchange rate policies. Available from: http://pubdocs.worldbank.org/en/543471500543123667/ECA2017-TJK-003.pdf

27. XE Currency Convertor. (2020). US dollar to Kyrgyzstani som conversion. Available from:<https://www.xe.com/currencyconverter/convert/? Amount=1\&From $=\mathrm{USD} \& \mathrm{To}=\mathrm{KGS}>$. [Accessed 20 December 2020]. 